AUTHOR:

Prof Dr. O.S. Sibanda (1)

https://orcid.org/0000-0001-5547-9600

AFFILIATION:

Faculty of Management and Law

University of Limpopo

CORRESPONDENCE TO:

Omphemetse.sibanda@ul.ac.za

DATES:

Published: 4 December 2020

HOW TO CITE THIS ARTICLE:

Sibanda, O.S., 2020. AfCTA and the

Trajectory of Industrialisation and

Development Sustainability in Africa

KOERS - Bulletin for Christian

Scholarship, 85(1). Available at: https://

doi.org/10.19108/KOERS.85.1.2484

COPYRIGHT:

(c) 2020. The Author(s)

Published under the Creative

Commons Attribution License.

\section{AfCTA and the Trajectory of Industrialisation and Development Sustainability in Africa}

\begin{abstract}
In 2018 the African Union Commission launched the first "Africa Industrialisation Week" to promote regional value chains development in Africa, to provide "A Pathway for Accelerating Africa's Structural Transformation, Industrialisation and Pharmaceutical Production". This paper will investigate the trajectory and key elements of Africa's industrialisation. In particular the paper will look into how the industrialisation will promote and enhance its sustainable development. Considered also will be harmonisation and regional integration; economic strategies beneficial for African countries; appropriate regulatory and policy regime; and issues structural transformation including reallocation of economic activities from less productive to more productive industrial sectors.
\end{abstract}

Keywords: Agenda 2063; Economic Acceleration; Economic Beneficiation, Harmonisation; Industrialisation, Intra-Africa Trade, Regional Integration, Regional Value Chains, Sustainable Development

\section{Introduction and Context}

In this paper we deal with the possible trajectory of Africa's industrialisation and the sustainability of development in Africa, particularly following the conclusion of the African Continental Free Trade Agreement (AfCFTA). In particular, the paper looks into how the industrialisation will promote and enhance its sustainable development in Africa. Key industrialisation and development considerations are discussed such as industrialisation regulatory framework, Africa's comparative advantage, structural transformation in both industry and governance structures, and labour re-orientation in the wake of the fourth industrial revolution (4IR). Industrialisation is an ever-present imperative for Africa to meet the objectives of Agenda 2063. It is a driver of sustainable economic growth in Africa (Opoku and Yan, 2018). Other drivers of sustainable and accelerated industrialisation include, but are not limited to, harmonisation and regional integration; economic strategies beneficial for African countries; appropriate regulatory and policy regime; and issues structural transformation. It should be noted, however, that the continent's countries will have different primary drivers of growth, which should be the starting point for industrialisation. In North Africa, for example, the Kenyan economy obtains major earnings from oil and gas, thus industrialisation must focus on these commodities (Khan, 2014). Similarly, in Sub-Saharan Africa, Nigeria's economic growth is driven by its hydrocarbon resources (Downie, 2014). Zambia, known as copper belt of Africa, has a strong copper output. Copper contributes 75\% of total Zambian exports (Downie, 2014).

AfCFTA aims to create Africa and the world's largest single market for trade in goods and services (Phakathi, 2019), which is now the largest free trade agreement worldwide (Phakathi 2019; Disenyana 2019) designed to achieve intra-African economic cooperation and integration. Important to note is that from 19 - 23 November 2018 the African Union Commission (AUC) launched the first Africa Industrialisation Week to promote regional value chains development in Africa. The idea behind this initiative is to provide A Pathway for Accelerating Africa's Structural Transformation, Industrialisation and Pharmaceutical 
Production. The Pathway also aligns to the objectives of AUC Africa's Agenda 2063: The Africa We Want, to transform and develop Africa by 2063, and also to the United Nations (UN) Sustainable Development Goals (SDGs). This an interesting development given the fact that both the United Nations Industrial Development Organisation (UNIDO) and the United Nations Conference on Trade and Development (UNCTAD) count Africa as one of the continents that has not leveraged its development on industrialisation and historically has the lowest Manufacturing Value Added (MVA) performance compared to other continents. Africa to date remains unindustrialised and the continent's development and economic wealth remain dependent mainly on "exporting primary commodities and importing manufactured goods" (Moyo, 2016:141. See also Dinh, 2016). Cilliers (2018) expressed a concern that Africa has been de-industrialising or "under-industrialised" and the "GDP in Africa has stagnated or contracted since the mid-1980s" (Cilliers, 2018:6). She juxtaposes Africa with Asia, where the latter benefits from rapid manufacturing as its most productive sector, and pursued the "growth-inducing structural transformation from low-productivity subsistence agriculture to high productivity manufacturing..." (Cilliers, 2018:4). On 29 July 2016, the United Nations General Assembly proclaimed that the period 2016-2025 as the Third Industrial Development Decade for Africa (IDDA III), and calling on UNECA, UNIDO, AU Commission, and NEPAD "to develop, operationalize and lead the implementation of the programme for the Third Decade, under its mandate and through voluntary contributions" (UNIDO, 2017).

\section{Principles and Foundational Basis for Economic Development}

Several theories exist as the foundational basis for economic and development studies, from classical theories to neoclassical and modern theories. Notable for this study are: North's institutional change theories (North, 1990), Adam Smith's theory of comparative advantage (Merlitz, 2003; Weder, 2003; Wacziarg \& Wallack, 2004; Sibanda, 2013; Sejkora \& Sankot, 2017) amplified by Porter's model for geographic competitive advantage (Kaufman, Gittell \& Merenda, 1994; Shehaan \& Foss, 2009); Marx's historical materialism theory of development (Meir, 1994), Walt Rostow's economic growth theory (Rostow, 1960), and Porter's development driver's modes (Bakhshinejad, 2014). Furthermore, this study is based on liberal and modified economic theoretical framework, which assumes that productive efficiency will be achieved once states rationalise costs and process of their production by undertaking economic production in areas where there is relative production advantage. It also conforms to the view that today no single theoretical framework can be used to understand the effects, challenges and opportunities presented by FTA such as AfCFTA.

The theoretical framework in this study is particularly informed by two consideration identified by Hoff and Stiglitz (1999), namely the forces that can explain the difference in GDPs across countries, and the possible implications the nature of the interventions designed to promote development. Furthermore, the execution of this study takes cognisance of the questions: Can a country experience sustained growth based solely on production and export of primary resources? Can a country experience long-term growth without industrialisation? If the country cannot do without industrialisation to reach the required level of development, how is industrialisation critical to sustained growth? (Ciarlie \& Maio, 2013).

North's theory posits that "one should examine institutions, changes in them, and their impact on economic performance over time through analyzing their interplay between entrepreneur agents (organizations) which are agents for change within (formal and informal) institutions" (Mizo, 2018:19). Given the topic of this paper about Industrialisation and the sustainability of development in Africa, this study relies primarily on the adjusted modernization theory of Walt W. Rostow, economic growth theory- The Take -off into SelfSustained Growth theory, as it addresses aspects of both development and sustainability 
irrespective of the development drivers in question. Rostow's theory is, in essence, the modification of Marx's stages theory of development, according to which capital accumulation to create economic growth is performed through both domestic savings and foreign investment (Meir, 1994). The Rostow model sets five stages of development through which an economy goes, namely: "the traditional society, the pre-conditions of take-off, the take-off, the drive to maturity, and the age of mass consumption" (Rostow, 1990). Africa has progressed beyond the Traditional Society stage, in terms of which development is characterized by a labour intensive subsistent, and agricultural-based economy with little trading practices. The Take-off stage is relevant to Africa in the context of AfCFTA because it speaks to a stage of intensive growth led by industrialization, which may lead to Drive to Maturity stage that will take place over some time supported by increased use of technology increases, economic growth and diversification.

Hunter articulates that economists agree that capital accumulation is not, and should not be, the only driver of economic development (Hunter, 2012). Other relevant models of development that considers the "cultural, political, social, institutional and geographical factors" (Hunter, 2012) are also relevant. In the light of this realisation, Murray Hunter points to Michael E. Porter's linear stage model of a country's economic development drivers is relevant. Porter's model looks into the country's development drivers and maintains that:

factor-driven economy gains its competitive advantage from natural resources, favourable conditions for growing crops, and low-cost labour sources, an investment-driven economy from the willingness of firms and individuals to invest in a modern plant, equipment, and technologies, an innovation-driven economy based on firms creating novel processes, products, and business models, and a wealth driven economy (also one in decline) where investment is based on the accumulated capital in low-risk ventures and activities like shopping centres (Hunter, 2012:26).

The above postulation by Porter fits the examination of development in Africa, though with limited adjustment. Hunter posits, and correctly so, that national economic development model is not a linear process. Therefore, economic development theories must not be cast in stone and must consider some realities such as the level of economic development of countries, unequal distribution of resources, the suitability of local topography, geographical location and infrastructure (Hunter, 2012). A typical example of the existing different levels of development in Africa is the view that Botswana and Mauritius are reputably known to be successful in fostering development, and are regarded as "as extraordinary cases of economic and political development in Africa" (Mizero, 2018:7).

\section{Sustainable development and industrialisation explained}

The concept of sustainable development has been the subject of many commentaries, academic discourses and explanations (Sampath, 2017). It suffices for this paper to state that sustainable development is a "common concern to both the developed and developing world" (Simuyi, 2014:374). Also that it is essentially an expression community and future humanity interests; an integrative principle which is an important part of the socio-economic development agenda (Simuyi, 2014; Oni et al, 1999).

Industrialisation can take many forms, in particular, export-orientated or imports-orientated industrialisation (Peters, 2013). A discussion on what industrialisation entails must, in my view, also include a reference to technological innovation and progresses as main drivers of "aggregate economic growth and improvements in living standards over the long term" (Bruckner, LaFleur \& Pitterle, 2017:4). In simple terms, industrialisation denotes an “economy driven by high-productivity activities in the manufacturing sector" (Moholwa, 2017:11). There 
has been extensive discussion in the economic literature about industrialisation as a sine qua non for development. Most prominent has been about the economies of scale and the controversy whether industrialisation displaces labour or lead to a re-allocation of labour (see generally Caraleo \& Pastore, 2010). The latter concern particularly relates to the fourth industrial revolution (4IR) - digital revolution to differentiate it to other three revolutions - and its "impact on inclusive and sustainable industrial development" (Dinh, 2016:4). The other revolutions are first revolution (1IR) of the $19^{\text {th }}$ century when steam power was used to supplement human labour; the second industrial revolution (2IR) which saw electricity been crucial to production; and the third industrial revolution (3IR) that heralded the internet age and information technology as pillars of growth and development. The current industrial revolution, the $4 \mathrm{IR}$, brings all the revolutions full cycle, with technological and human capacities nested in innovations and production. There is, for example, 3D printing in manufacturing/production prototypes, big data analytics and self-driving vehicles (See Schäfer, 2018; Xu David \& Kim, 2018).

The technological revolution of the 4IR is viewed in the light of its impact on the labour market, be it "job destruction" or "job creation" (Bruckner, LaFleur \& Pitterle, 2017:1). The view is that industry mechanisation and productivity gains from technology-led business models may lead to declines in certain areas of employment such as the agricultural sector and those industries reliant on manual labour (Bruckner, LaFleur \& Pitterle, 2017). The consequences of industrialisation will vary based on the industry type and how it is implemented. Industrialisation is not always the cause of declines in employment. Moholwa (2017), for example, reports that the South African economy has been experiencing deindustrialisation and rising levels of inequality, unemployment and poverty. The country's economic growth is dependent primarily on the export of primary commodities and household consumption. This state of affairs promoted the South African Government to adopt a National Industrial Policy Framework (NIPF), realised through the Industrial Policy Action Plan (IPAP) to promote re-industrialisation (Moholwa, 2017).

\section{4. $\quad \mathrm{AU}$ and the quest for industrialisation}

Numerous studies have affirmed the importance of industrialisation and its varying degrees of importance. For example, industrialisation is said to be: a major contributor to the country's income levels (Moyo, 2016, quoting Owusu \& Samatar, 1997:3); a source of generation of employment and enhancement of development (Moyo, 2016); enabler and promoter of economic diversity that can shield the country's economy to "negative external shocks" (Moyo 2016:143); and other inhibitors of progressive development. Industrialisation is equally a political issue as it is an economic issue (Moyo, 2016). The interconnectedness of economic growth and political stability is often revealed through the fragility of the country's economic performance when there is governance uncertainty, labour and political unrest. The economic activity that will always experience tremors as a result of these conditions will be investment and currency performance. According to Abaayo (1999) "bad governance has contributed to the slow pace of development in Africa, which has been demonstrated through many things including unrealistic development policy framework". This has also been consequent to issues of political legitimacy of certain government (Schatzber, 2001). Thus, it remains both a topical and contentious issue. Other issues that have stunted Africa's development, such as conflicts that have had destructive impacts on the continent's economic and social fabric, will not be discussed in this paper as they have been addressed sufficiently somewhere (see Bakare, 2014).

Before the launch of the first-ever Africa Industrialisation Week, the AU has already had discussions and some commitments on the need for industrialisation. For instance, the 10th African Union (AU) General Assembly held in Addis Ababa, Ethiopia, in January 2008, was dedicated to the industrialisation of Africa (Moyo, 2016) and ended with the adoption of the Action Plan for Accelerated Industrial Development of Africa (AIDA). State Parties also 
acknowledged the centrality of the development of the intense industrial sector to achieving socio-economic welfare (Moyo, 2016). It is noted, for example, that the 2009 economic crisis hit adversely countries such as Namibia, Botswana, South Africa, Zambia, Congo DRC and Kenya, which were "[r]esource-dependent and primary-commodity exporters" (Moyo, 2016:141) in their developmental and economic welfare designs.

The African Development Bank's Africa Economic Outlook of 2018 reflects African economies as resilient, having recovered their growth stimulus specifically in non-resource-intensive economies and regained momentum since the 2009 economic crisis (AfDB, 2018). According to the Bank, the "[r]eal output growth is estimated to have increased 3.6 percent in 2017 and to accelerate to 4.1 percent in 2018 and 2019" (AfDB, 2018:4). However, industrialisation as the driving force behind this growth and development is still lagging. The causes of retardation of industrialisation in Africa and nullification of the continent's comparative advantage have been identified to include variables such as "[i]nsufficient stock of productive infrastructure in power, water, and transport services..." (AfDB, 2018: xvi). For example, over 640 million Africans are reported to be without access to electricity and the proportion of electricity access rate in Africa is more than 40 percent low globally compared (AfDB 2018). For instance, the per capita consumption of electrical energy in "Sub-Saharan Africa (excluding South Africa) is $180 \mathrm{kWh}$, against 13,000 kWh per capita in the United States and 6,500 kWh in Europe" (AfDB, 2018:68). This statistical information further demonstrates the challenge of Africa been left behind concerning industrialisation. Though South Africa is excluded from Sub-Saharan Africa's per capita consumption of electrical energy, a conclusion must not be drawn that the country is far ahead of others in terms of technological achievement in sustainable electricity supply sector.

\section{Key industrialisation and development considerations 5.1 Sound Industrialisation Strategy, Regulatory and Policy Framework}

There is going to be a need for a continental industrialisation strategy around which AfCFTA industrialisation and sustainability objectives will be realised. Such a strategy, which must trickle down to national authorities, must have certain minimum conditions and/or characteristics. Yet, it is also important that the country-specific context is always taken into account (Joffe, Kaplan, Kaplinsky and Lewis, 1995). Factors other than economic considerations must be taken into account. The following four aspects of industrial strategy highlighted by Best (1990:265-6) are noteworthy and important to consider: (1) the encouragement of competition, (2) the seeking of a balance between co-operation and competition, (3) no planning industries of the future, but rather an examination of the requirements for sustaining competitive success and work to ensure that firms, which provide the real dynamic thrust, can respond quickly as new markets emerge, and (4) the need for independence, but hands-on industry studies and the integration of 'thinkers and doers' from different institutions that are able and willing to think long term.

\subsection{Leveraging on Comparative Advantage}

Adam Smith's theory of absolute advantage from his pioneering work, Undersøgelser om National-Velstands Naturog Aars ag (Wealth of Nations) and later modified by David Ricardo as a comparative advantage (CA) in the work Principles of Economics, proposes that a nation must trade in goods it can produce relatively cheap or services it can render at affordable wages (Sejkora \& Sankot, 2017; Sibanda, 2013; Wacziarg \& Wallack, 2004; Weder, 2003; Merlitz, 2003; Porter, 1990). Comparative advantage "exists for an economy if the cost of producing that good or service is relatively lower for that economy than of any other economy" (Sibanda, 2013:822). In terms of CA, for example, South Africa should leverage export of maize meal instead of rice because it has a comparative advantage for producing maize by industrialised and technologically advanced farmers compared to rice that is produced by small subsistence and/or small-hold farmers (Sibanda, 2013). Rice production 
and exportation must be left to high-yielding areas of irrigated rice found in China, Egypt, Thailand, and the Senegal River Valley in Africa, for example. Moholwa (2017:63) argues that "South Africa must use its comparative advantage by focusing on "product-enhanced structural transformation in the manufacturing sector (trade, transport, and mining sectors)" to promote and stimulate economic growth and development.

In Ethiopia, for example, agriculture contributes $45 \%$ of the GDP and thus the largest revenue generator of the country, yet the country is the net food importer with increasing food import dependency (Cilliers, 2018). In my view, this should not have been the case. Ethiopia must invest in the structural transformation of its industrial section making it more technologically efficient, and consequently a sector that can give it a comparative advantage. But, it may depend also on the labour costs in Ethiopia. Poor African countries are known to have high labour cost (Cilliers, 2018), making them unable to leverage their comparative advantage in certain sectors and to industrialise. Another example, Senegal, may harness its comparative advantage in a certain sector. The country is a middle-income country with very modest economic growth (Sejkora \& Sankot, 2017). But the empirical study by Sejkora \& Sankot (2017) revealed that Senegal has a sector with CA related to chemicals, which in my view must be highly industrialised to give Senegal a competitive edge. Chingarande Mzumara and Karambakuwa (2013) report that Kenya is a specialist producer of green tea compared to Uganda that produces black tea. Furthermore, Kenya has CA in cut flowers while Uganda specialises in roses (Chingarande Mzumara \& Karambakuwa, 2013). Therefore in between them, Kenya must import black tea and export green tea, while Uganda must export black tea and import green tea. Kenya may dispense with a nursery of roses and import them from Uganda.

To optimally benefit from the AfCFTA arrangements member states must prioritise developing their industries and trading in products they possess the competitive advantage in.

\subsection{Structural Transformation: Infrastructure, Manufacturing and Production Structures}

Structural transformation (ST) broadly understood includes the reallocation of economic activities from less productive to more productive industrial sectors. The idea is that transformation must generate more value add, including increased job creation and poverty reduction. According to the AfDB, there has been a slow pace of ST in Africa, and little has been done in bringing large and permanent changes to the structure of production that exclude the extractive industries (AfDB, 2018). In the agricultural sector, for example, there must be more investment, modernisation of production processes, and introducing other measures aimed at developing agricultural value chains (AfDB 2018). ST may need huge base funding giving the level of development of African countries and their budgetary abilities (AfDB, 2018).

High-quality, effective and efficient infrastructure is critical for Africa to realise the SDGs, Agenda 2063, and the High Five Goals of the AfDB. Just to note, Agenda 2063 sets manifold objectives some of which a critical to industrialisation. For instance, it calls for the establishment effective and efficient transport and logistics infrastructure in the form of air and maritime transport Network, a continental road and rail network, education, adequate health facilities, and modernised communication network (AfDB, 2018). Sustainable economic growth and development are highly dependent on infrastructure. "If transport, electricity, or telecom services are absent or unreliable, firms face additional costs (buying power generators, for instance) and struggle to adopt new technologies. Better transport increases the effective size of labour markets," noted the African Development Bank (AfDB, 2018:65). UN Goal 9 on Industry, innovation and infrastructure makes it clear that investing in infrastructure and innovation is important to drive economic growth and development (WEF, 2019). 
According to the UN Economic for Africa Index Sudan has the least developed and modest infrastructure while South Africa ranks the highest in the continent regarding economic infrastructure (Phakathi, 2009). The situation needs to change to enable activation of AfCFTA goals and objectives on continental economic integration and growth.

\subsection{Structural Transformation: Democratic Governance Structures}

Ezechukwunyere (2018) makes a compelling argument on the struggle still experienced by the $A U$ in meeting its sustainable development and economic integration objectives. This, in my view, remains a concern even with the implementation of AfCFTA. According to Ezechukwunyere (2018), the problem is attributable to the democratic governance deficit in the organisational architecture of the AU portrayed through the weak governance structure and without the political will to implement organisational objectives, for example. Interestingly, Ezechukwunyere (2018) points to a connection between the sustainability of development in Africa and democratic governance. Thus, the author calls for the prioritization of democratic governance as a necessary pre-condition and /or complementary to economic development particularly within the framework of Agenda 2063.

Osabu-Kle (2000) argues that "only a democracy compatible with the African cultural environment is capable of achieving the political conditions for successful development in Africa." A similar view is held by Solomon and Liebenberg (2000), who refers to the South African experience of democratization, express a viewpoint of African democratization that is undergirded by African realities and challenges. This viewpoint is debatable, at least from the position of an economics scholar. Admittedly, African cultural contexts cannot be ignored when considering the democratic culture of institutions that will implement AfCFTA. For instance, Sibanda (2012) uses the principles of Ubuntu to demonstrate how the World Trade Organisation (WTO) dispute settlement processes can invoke African justice paradigms, and how a reference to morality in Article 20 of General Agreement on Trade and Tariffs (GATT) can cover morality in terms of the values and principles of uBuntu (Sibanda 2005). A similar position can be taken concerning dispute settlement under AfCFTA as discussed below.

\subsection{Re-Orientation of the WorkForce}

Related to ST and industrialisation in the age of FTAs has been a concern that labour may be re-allocated and the rate of unemployment increased. A study by Caraleo and Pastore (2010) indicated otherwise, who argues that: “During periods of structural change, worker reallocation is more apparent, but it reduces at later stages...Several possible explanations have been raised of the spatial correlation between the degree of reallocation of labour and unemployment: first is the higher degree of structural change; second is the presence of asymmetric effects of aggregate disturbances..."(Caraleo and Pastore, 2010:42043). The reality is that industrialisation will always involve re-allocation of labour, and in some cases, it may even include displacement of the workforce. It is therefore important that the current workforce is fully prepared for industrialisation. This is particularly imperative in the light of the 4IR, which has at the centre of the production mechanisation and IT tools. Industrialisation as economic growth and development strategy will impact employment scales.

\section{Conclusions, recommendations and the way forward}

Considered jointly and severally, A Pathway for Accelerating Africa's Structural Transformation, Industrialisation and Pharmaceutical Production and the industrialisation and development demands of the AfCFTA present yet the dawn of another period of an attempt at the widescale development of the African continent. To emancipate Africa from being the begging child of global nations. It is hoped the industrialisation and sustainable development introduced and/or raised in many African instruments including NEPAD will for once bear fruit. 
Of course, much will have to be done to see to it that tangible results are achieved. Among others, African governments have clear industrialisation policy options to follow, with their associated short and long term plans. Part of the plans must be to address all structural transformation issues. They must be the "the right kinds of policies for overall sustainable development "by creating a balance between environment, development and equity" (Sampath, 2014:541). There is also a need to revisit labour standards and employment condition taking into account the need to secure jobs on the one hand and striking the right kind of balance between technology and human skills (Sampath, 2014). Most importantly, the $\mathrm{AU}$ to take lead in implementing credible and committed leadership based on sound economic development principles. To this end, there must be a strong political will from AfCFTA countries to implements the Agreements and its associated protocols and side agreements.

\section{References}

Abaayo, O.J. 1999. The Power Base behind Under-development in Post-independent Africa: A Tentative Approach through Scenario Building. Kenyatta University: Nairobi, Kenya.

African Development Bank (AfDB). 2018. Africa Economic Outlook 2018.

African Union Commission. Agenda 2063 Framework Document. Available at: http://www.un.org/en/ africa/osaa/pdf/au/agenda2063-framework.pdf (Accessed on 20 February 2019).

AU: African Charter on the Values and Principles of Public Service and Administration: adopted on 31 January 31

Bakare, A.R. 2014. African Union and the Developmental Transformation of Africa: Challenges, Achievement and Prospects. European Journal of Sustainable Development 3(1): 67-86.

Bakhshinejad, M. 2014. Porter's Competitive Advantage Model and its Application in Bottled Drinking Water in Iran. Agricultura Tropica et Subtropica, 47(2): 60-67. https://doi.org/10.2478/ats-2014-0008.

Bruckner, M., LaFleur, M. \& Pitterle, I. 2017. The impact of the technological revolution on labour markets and income distribution. Frontier Issues, 1-49. Available at: https://www.un.org/development/desa/ dpad/wp-content/uploads/sites/45/publication/2017_Aug_Frontier-Issues-1.pdf.

Caroleo, F.E. \& Pastore, F. 2010. Structural Change and Labour Reallocation Across Regions: A Review of the Literature In F.E. Caroleo and F. Pastore (eds.), The Labour Market Impact of the EU Enlargement. AIEL Series in Labour Economics: Springer. https://doi.org/10.1007/978-3-7908-2164-2_2.

Chingarande A., Mzumara M., and Karambakuwa R. 2013. Comparative Advantage and Economic Performance of East African Community (EAC) the Member States. Journal of Economics, 4(1): 39. https://doi.org/10.1080/09765239.2013.11884963.

Ciarlie, T. \& Maio, M.D. 2013. Theoretical arguments for industrialisation driven growth and development. In Matambalya FAST. African Industrial development and European Co-Operation. Routledge.

Cilliers, J. 2018. Made in Africa: 2018. Manufacturing and the fourth industrial revolution. Africa in World Report 8. Institute for Security Studies.

Dinh, D.D. 2016. Industrialisation in Africa and Least Developed Countries: Boosting growth, creating jobs, promoting inclusiveness and sustainability. Available at: https://www.uvic.ca/research/centres/ capi/assets/docs/Dinh_Sustainable_Industrialisation.pdf.

Disenyana, T. 2019. The AFCFTA - lessons from the free trade area of the Americas. Business Day, 27 March 2019. Available at: https://www.businesslive.co.za/bd/opinion/2019-03-27-the-AfCFTA-lessons-from-the-free-trade-area-of-the-americas/ .

Downie, A. 2014. Economic review: Sub-Saharan Africa. In Voisey N., Slocombe A \& Haley G (ed). Developing Loan Markets. Loan Market Association: London.

Ezechukwunyere, N.O. 2018. The African Union Agenda 2063 and the Imperative of Democratic Governance. The Law and Development Review, 11(2):259. https://doi.org/10.1515/ldr-2018-0019.

Hunter, M. 2012. The Stages of Economic Development from an Opportunity Perspective. Rostow Extended. Geopolitics, History, and International Relations, 4(2):25-55.

Hoff, K. \& Stiglitz, J.E. 1992. Modern Economic Theory and Development. The World Bank, 1-69. Available at: https://sites.hks.harvard.edu/cid/archive/events/cidneudc/papers/neudcstiglitz.pdf. 
Joffe, A., Kaplan, D., Kaplinsky, R. \& Lewis, D. 1995. Improving Manufacturing Performance in South Africa - The Report of the Industrial Strategy Project, Industrial Strategy Project. International Development Research Centre, UCT Press: University of Cape Town.

Melitz, M.J. 2003. The impact of trade on intra-industry reallocations and aggregate industry productivity. Econometrica, 71(6):1695. https://doi.org/10.1111/1468-0262.00467.

Moholwa, M. 2017. The Impact of re-industrialisation on economic growth and employment in South Africa. MBA: University of Pretoria

Moyo, T. 2016. Promoting Industrialisation in Mauritius, South Africa and Botswana: Lessons for the Future. Africa Development, XLI (3):139.

North, D.C. 1990. Institutions, Institutional Change and Economic Performance. Cambridge: Cambridge University Press.

Oni, S.B., Ayanniyi, A.B., Ogunwale, SA. \& Omolehin, A.R.A. 1999. Policies and Strategies for Sustainable Development in Africa South of Sahara: Proceedings of Series of Workshops for Top Level Local Government Officers Held All over the States in Nigeria, 1993-1994. Society for International Development Publication: Nigeria

Opoku, E.E.S. \& Yan, I.K.M. 2018. Industrialisation as a driver of sustainable economic growth in Africa.

Osabu-Kle, D.T. 2000. Compatible Cultural Democracy: The Key to Development in Africa. Broadview Press: Peterborough, Ontario. https://doi.org/10.3138/9781442602472.

Peters, E.D. 2013. Are NAFTA and Export-oriented Industrialisation Passé for Mexico's Economy? Global Lessons. In Bardhan A, Jaffee D \& Kroll C. The Oxford Handbook of Offshoring and Global Employment. https://doi.org/10.1093/oxfordhb/9780199765904.013.0022.

Phakathi, B. 2019. Regional Integration in Africa remains low. Business Day, 25 March 2019. Available at: https://www.businesslive.co.za/bd/national/2019-03-25-regional-integration-in-africa-remainslow/.

Porter, M.E. 1990. The Competitive Advantage of Nations. New York, NY: The Free Press.

Khan, A. 2013. Economic Review: North Africa. In Voisey, N., Slocombe, A. \& Haley, G. (ed). Developing Loan Markets. Loan Market Association: London.

Rostow, W.W. 1960. The Stages of Economic Growth: A Non-communist Manifesto. Cambridge: Cambridge University Press.

SA: Industrial Policy Action Plan (IPAP) 2018/19 - 2020/21. Available at: https://www.gov.za/sites/ default/files/gcis_document/201805/industrial-policy-action-plan.pdf.

SA: National Industrial Policy Framework. Available at: https://www.gov.za/sites/default/files/gcis document/201409/national-industrial-framework-policy04032008.pdf.

Sampath, P.G. 2014. Sustainable Industrialisation in Africa: Toward a New Development Agenda. African Journal of Science, Technology, Innovation and Development, 6(5):439.

Schäfer, M. 2018. The fourth industrial revolution: How the EU can lead it. European View, 17(1):5. https://doi.org/10.1177/1781685818762890.

Schatzberg, M.G. 2001. Political Legitimacy in Middle Africa: Father, Family, Food. Indiana University Press: Bloomington

Sejkora, J. \& Sankot, O. 2017. Comparative advantage, economic structure and growth: The case of Senegal. South African Journal of Economic and Management Sciences, 20(1):1685. https://doi. org/10.4102/sajems.v20i1.1685.

Sibanda, O.S. 2005. Human Rights Approach to WTO Trade Policy: Another Medium for the Protection of Human Rights in Africa, and Elsewhere, African Journal of Human Rights, 5:387.

Sibanda, O.S. 2012. Towards the African Philosophy of Ubuntu as an Interpretive Principles in the WTO Dispute Settlement Proceedings In SM Kirkegaard (ed) Law, Governance and World Order 525-523. International Association of IT Lawyers: Ankara, Turkey.

Sibanda, O.S. 2013. Trade liberalisation and its impact on food security in Sub-Saharan Africa: The Case for the Agricultural Sector Play? In Kirkegaard, S.M (ed) Law and Practice: Critical analysis and Legal Reasoning. International Association of IT Lawyers: Turkey.

Simuyi, F. 2014. Rethinking \& Recasting Bilateral Investment Treaties as Integrative Tools for Sustainable Development: The Kenyan Experience. European Journal of Sustainable Development, 3(3):373. https:// doi.org/10.14207/ejsd.2014.v3n3p373. 
Smith, A. 1779. Undersøgelser om National-Velstands Natur og Aars ag (Wealth of Nations), trans. Frantz Dræbye. Copenhagen: Gyldendals.

Solomon, H. \& Liebenberg, I. 2000. Consolidation of Democracy in Africa: A View from the South. Ashgate: UK.

Wacziarg, R. \& Wallack, J.S. 2004. Trade liberalization and inter-sectoral labour movements. Journal of International Economics, 64(2):411. https://doi.org/10.1016/j.jinteco.2003.10.001.

Weder, R. 2003. Comparative home-market advantage: An empirical analysis of British and American exports. Review of World Economics, 139(2): 220. https://doi.org/10.1007/bf02659744.

World Economic Forum. Accelerating a more sustainable industrial revolution with digital manufacturing. 10 January 2019. Available at: https://www.weforum.org/agenda/2019/01/3d-printing-fourthindustrial-revolution-sustainable/.

Xu, M., David, J.M. \& Kim, S.H. 2018. The Fourth Industrial Revolution: Opportunities and Challenges. International Journal of Financial Research, 9(2):90. 